\title{
Neurosciences in Hellenistic Alexandria
}

Keywords: neurosciences, Hellenistic period, Alexandria, neurophilosophy, erasistratus, herophilus

\section{Editorial}

The Hellenistic Era is a three century period of Mediterranean History, starting from the death of Alexander the Great in $323 \mathrm{BC}$ and lasting to the final domination of Rome in $31 \mathrm{BC}$, after the battle of Action. This period was one of the most important in the history of Neurosciences, since it was the time of harmonious amalgamation of Neurosciences with Philosophy. ${ }^{1}$ Among the numerous academic centers of Hellenistic Antiquity, Alexandria, founded in $331 \mathrm{BC}$, by Alexander the Great, became under the Ptolemaic dynasty a leading cosmopolitan center of Civilization, Philosophy, Science and Education, a real arsenal of scientific knowledge and culture, which was playing a decisive role upon the civilization of the Late Antiquity, the Islamic middle age and the Modern European Science.

Neurosciences possessed a dominant place in the Hellenistic School of Medicine. ${ }^{2}$ The brain as the organ of mind and intelligence, closely related with the soul, the center of the conscious life and reasoning, attracted the attention of physicians, philosophers and many intellectuals in other disciplines. In Alexandria, the Hippocratic Medicine was enriched by many original, important observations on Anatomy and Physiology of the Nervous System by the eminent Physicians of the School of Alexandria, who were also deeply influenced by the rich philosophical background of the Hellenistic world.

In the field of Philosophy Alexandria became after Athens the center of a distinctive kind of Platonism, named Neo-Platonism, introduced by Plotinus (205-270 AC), a moral platonic teacher, who wrote his philosophical dissertations in the form of six sets of nine treatises each, called Enneads (Evvé́ $\delta \varepsilon \varsigma) .{ }^{3}$ According to Plotinus the mind and the soul are eternal. Man can ascent by his own mind to the level of the universal soul, where he could find the universal peace and harmony. ${ }^{4}$ The feeling of the interior harmony and the eventual union with the One is the principal purpose of the human life. Porphyry (Порфúpios) (234-305 AD), a devoted disciple of Plotinus emphasized the concept of the dissociation from the corporal care as an essential condition for elevating to the real freedom of the human being. ${ }^{6}$ According to Porphyry (Порфv́pıos) Being, Life and Intellect are phases in the eternal self-determination of the ultimate reality. The moral purification and the intellectual enlightenment are the real ways to union with the Truth. ${ }^{7}$

The Stoicism, ${ }^{8}$ a philosophical doctrine introduced by Zenon of Citium, who wrote a philosophical dissertation on the nature of the

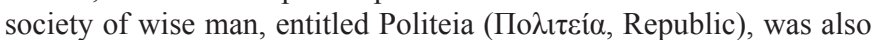
flourished in Ptolemaic Alexandria. Zenon was considering the end

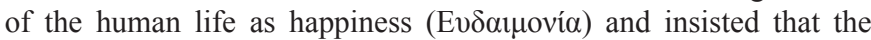
real way to happiness is the honest and virtual life in agreement with

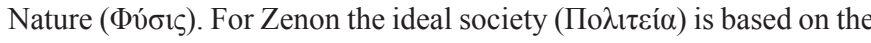
moral perfection.

Chrysippus, one of the most important stoic philosophers, a scholar of great erudition, claimed that Nature is a creative, rational force and its manifestations are both the right and the goodness. ${ }^{9}$ The
Volume 8 Issue 5 - 2018

\author{
Stavros J Baloyannis \\ Research Institute for Alzheimer's disease, Aristotelian \\ University, Greece
}

Correspondence: Stavros ] Baloyannis, Professor Emeritus, Aristotelian Univesity, Angelaki 5, Thessaloniki 5462I, Greece, Tel +302310270434, Fax +302310270434, Email sibh844@otenet.gr

Received: August 31, 2018| Published: September 14, 2018

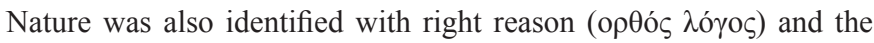
Law, known as natural law, which is in harmony with the reason of the universe. The wise man has a fully developed reasonable thinking

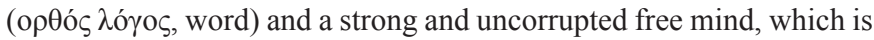
in harmony with the logos of the universe, acting always in agreement with the Nature. ${ }^{10}$ All the human passions, according to Chrysippus,

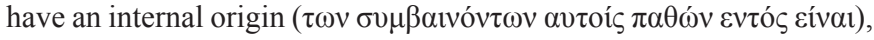
given that the real cause is found inside the mind and the soul of the person who suffers, a concept which has had a tremendous impact on the psychosomatic Medicine. Eratosthenes a disciple of Zeno, who become librarian, in the famous Library of Alexandria, probably in the 240 BC., exercised great influence in Alexandrian political life.

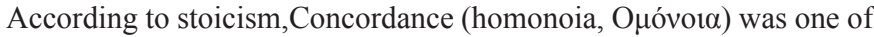
the fundamental political principles for leading to common good and benefaction of all. ${ }^{11}$

In Alexandria the Neurosciences flourished, under the enlightened government and liberal opinions of Ptolemy the Savor $(\Sigma \omega \tau \eta \dot{\rho})$ and his immediate successors Philadelphus ( $\Phi \uparrow \lambda \alpha ́ \delta \varepsilon \lambda \varphi \circ \varsigma$ ) and Euergetes, who patronized science and philosophy and encouraged scientific research. Ptolemeus Philadelphus ( $\Phi \uparrow \lambda \alpha \dot{\alpha} \delta \varepsilon \lambda \varphi \circ \varsigma)$ was the first sovereign of the Hellenistic era, who allowed physicians to proceed in dissection of the human body for the study of the topographic Anatomy. Among the famous physicians of the Hellenistic Era in Alexandria, the most

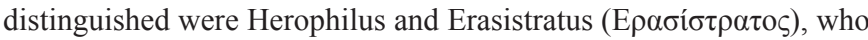
were also the first anatomists of the central nervous system in the history of Neurosciences. ${ }^{12}$

Herophilus ${ }^{13}$ is well known from his theory of the great diagnostic value of the pulse in heart diseases and stroke, maintaining that the pulse is not an innate faculty of the arteries, but it is derived directly from the heart. He invented and introduced in the clinical practice the portable water-clock in order to measure the pulse of the patients accurately. ${ }^{14}$ However Herophilus was involved mainly in Neuroanatomy and Clinical Neurology. ${ }^{15} \mathrm{He}$ used to excise the brain from the skull in order to study its structure, making three dimensional sections for the precise stereotactic perception of the brain, describing at the same time, the vascular supply, the meanings, the ventricular system and the subcortical gray matter. ${ }^{16}$

It is well documented that Herophilus described the durra matter and the venous sinuses of the skull, particularly the straight venous sinus and the confluence of the sinuses on the internal occipital protuberance, in the inner surface of the occipital bone, which is 
called after him “Torcula Herophili”. In addition Herophilus described the groove in the floor of the fourth ventricle and compared the lower angle of the floor to reed pens, calling it "calamus scriptorius", ( plexuses, in the cerebral ventricles and called them choroid plexuses or vascular membranes. Herophilus strongly believed that the ventricles are the seat of the human intelligence. Herophilus proceeded also in detailed dissection and description of the cranial and spinal nerves, distinguishing them and their roots into sensory and motor ones. ${ }^{17}$

Herophilus by his meticulous neuroanatomical observations concluded that the brain was definitely the dominant organ in Man (the hegemonicon, the governing principle of the body), which motivates and controls all bodily actions and activities. ${ }^{18}$

Erasistratus of Chios or Ceos (304-250 BC) was recognized as one of the most famous neurologists in the Hellenistic period. $\mathrm{He}$ was the first who attempted to combine Neuroanatomy with Neurophysiology. ${ }^{19}$ Erasistratus, performing numerous dissections of the central nervous system, described the four ventricles of the brain ${ }^{20}$ and studied extensively the morphology of the gyri and sulci of the surface of the brain hemispheres, also claiming so that the centers of the higher mental faculties are located on the various cortical areas of the lobes of the brain hemispheres, supporting with enthusiasm the encephalocentric theory of cognition and psychic function, in contrast to Aristotelian cardiocentric doctrines. ${ }^{21,22}$

Erasistratus hypothesized that the large number of gyri of the human brain, in comparison with the animals, is presumably related to the superior cognition of humans. Erasistratus made also a sharp distinction between the structure of the cerebral and the cerebellar cortex and underlined the important role that the cerebellum would play in the harmony ( $\left.\varepsilon v \tau \alpha \xi^{\prime} \alpha\right)$ of the movements. On the peripheral nerves Erasistratus claimed that they are solid structures, composed of microtubules that communicate directly with the brain stem and the spinal cord. According to Erasistratus, the vital spirit reaches the brain by the blood circulation and it is transformed inside the brain's substance into animal spirit, which is transmitted subsequently to all of the organs, the parts of the body and the muscles, via the cranial and the spinal nerves, vitalizing the human existence. ${ }^{23}$

Erasistratus was the first physician who distinguished the physical from the psychological disorders and he was introducing methods of psychotherapy and music therapy ${ }^{24}$ in order to treat patients who suffered from psychosomatic syndromes, as he did in the case of the serious psychosomatic disorder of Antiochus, son of the Seleucus the Nicator, King of Syria, who was involved in a serious emotional problem and he thought to bring his life slowly to extinction by neglecting his person and refusing nourishment. Erasistratus treated Antiochus enabling him to give the proper solution of his emotional distress.

Based on Herophilus and Erasistratus therapeutics, as well as on Hippocratic Corpus and Galen dissertations Pedanius Dioscurides, a physician and pharmacologist who resided in Rome during the first century ${ }^{25}$ composed a 5 -volume compendium on Medical Material

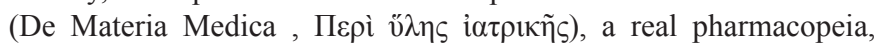
which was widely read, studied and used in the clinical practice for more than 1,500years. ${ }^{26,27}$

Hellenistic Neurosciences plot the pattern of Byzantine and Arabic Neurology ${ }^{28}$ and exercised a strong and long lasting influence on the modern Neurology.

On the importance of the amalgamation of philosophy with neurosciences for the treatment of psychosomatic disorders, Galen from Pergamum, one of the most eminent Greek physicians, stated that the physician has to master all aspects of philosophy, logic, natural sciences and ethics... then each physician must evidently be in need of philosophy, and each physician has to be a real philosopher...' ${ }^{29,30}$

\section{Acknowledgements}

None.

\section{Conflict of interest}

The author declares no conflict of interest.

\section{References}

1. Baloyannis SJ. The Neurosciences in the Greek World. In KK Sinha, et al. editors. Some aspects of history of Neurosciences. Ranchi: Catholic Press; 2003. p. 97-117.

2. Souques A. Etapes de la neurology dans antiquité Greque. Masson Paris; 1936.

3. Davarinou PG. Plotinus'attempts to go beyond the Platonic philosophy, Thesis, Athens, Greece; 1995.

4. Gary JSM. Plotinus on the soul's omnipresence in body. International Journal of the Platonic Tradition. 2008;2(2):113-127.

5. Plotinus. Greek text with English translation by AH Armstrong. Cambridge, UK: MA Loeb Classical Library; 1968;(7).

6. Porphyry. On Aristotle's Categories. Translated by Steven K. Strange, Ithaca, NY: Cornell University Press; 1992.

7. Karamanolis G, Sheppard A. Studies on Porphyry. London: Institute of Classical Studies, University of London; 2007. 183 p.

8. Erskine A. The Hellenistic Stoa. Ithaca, New York: Cornell University Press; 1990.

9. Diogenes Laërtius. The Lives and Opinions of Eminent Philosophers. In: CD Yonge, editor. London: George Bell Sons; 1895.

10. Brehier E. Chrysippe et l'Ancien Stoïcisme. Paris: Presse Universitaire de France; 1951.

11. von Arnim H. Stoicorum Veterum Fragmenta. Stuttgart; 1903.

12. Reverón RR. Herophilus and Erasistratus, pioneers of human anatomical dissection. Vesalius. 2014;20(1):55-58.

13. Dobson JF. Herophilus of Alexandria. Proc R Soc Med. 1925;1:19-32.

14. Von Staden H. Herophilus, The art of medicine in early Alexandria. Cambridge: Cambridge University Press; 1989.

15. PearceJMS. Neuroanatomy of Herophilus. Eur Neurol. 2013;69(5):292295.

16. Bay NS, Bay BH. Greek anatomist Herophilus: the father of anatomy. Anat Cell Biol. 2010;43(4):280-283.

17. Tomey MI, Komotar RJ, Mocco J. Herophilus, Erasistratus, Aretaeus, and Galen: ancient roots of the Bell-Magendie law. Neurosurg Focus. 2007;23(1):E12.

18. Singer C. The Legacy of Greece. Livingstone RW editor. Oxford, Clarendon Press; 1921.

19. Brock AJ. Erasistratus. 'On Paralysis'. In: Greek Medicine: Being Extracts Illustrative of Medical Writers from Hippocrates to Galen; 1921.

20. Pearce JMS. The Neurology of Erasistratus. J Neurol Disord. 2013;1:111.

21. Aristotle. De anima. Greek text and English transl. by WS Hett. London 
W. Heinemann, Cambridge MA Harvard University Press; 1957.

22. Aristotle Meta. 4;985 a 18., De Anima III, 4, 429 a 22-24, 10-13, V, 430 a $22-23$.

23. Longrigg J. Superlative achievement and comparative neglect: Alexandrian medical science and modern historical research. Hist Sci. 1981;19(45 pt 3):155-200.

24. Baloyannis SJ. The psychotherapy in the antiquity. Annals of the School of Theology. Aristotelian University Press; 1992. p. 432-438.

25. Allbutt TC. Greek medicine in Rome. London: Macmillan; 1921. 647 p.
26. Forbes A, Henley D, Henley D. 'Pedanius Dioscorides' in: Health and Well Being: A Medieval Guide. Chiang Mai, Cognoscenti Books; 2013.

27. Sadek MM. The Arabic materiamedica of Dioscorides. Québec, Canada: Les Éditions du sphinx; 1983.

28. Baloyannis SJ. Avicenna: The mysticism of the Greek medicine in the Arabian World. Encephalos. 1997;34:11-29.

29. Galen. Opera Omnia. In: DCG Kuhen. Gnobloch, Leipzig; 22:18211833.

30. Galen. On the natural faculties English transl. by AJ Brock. London W. Heinemann, Cambridge MA Harvard University Press, 1963. 